\title{
ESTIMATION OF CARBON RESERVED IN MANGROVE FOREST OF SUNGAI SEMBILAN SUB-DISTRICT, DUMAI CITY, RIAU PROVINCE
}

\author{
Edi Handoyo ${ }^{1^{*}}$, Bintal Amin $^{2}$, Elizal $^{2}$ \\ ${ }^{1}$ Student of The Faculty of Fisheries and Marine Universitas Riau, Pekanbaru \\ ${ }^{2}$ Lecturer at The Faculty of Fisheries and Marine Universitas Riau, Pekanbaru \\ *edihandoyo.eh@gmail.com
}

\begin{abstract}
Increasing $\mathrm{CO}_{2}$ concentration in the atmosphere is one of the factor which cause global warming. $\mathrm{CO}_{2}$ sequestration through mangrove forests is believed to be one of the efforts to reduce $\mathrm{CO}_{2}$ in atmosphere. This research was conducted in July 2019, aimed at estimating mangrove biomass, mangrove carbon stocks, soil organic carbon, and $\mathrm{CO} 2$ sequestration in mangrove forests in the coastal areas of Sungai Sembilan District, Dumai City, Riau Province. This research was conducted using the line transect plot method. Sampling is done by nondestructive sampling by measuring DBH (Diameter at Breast Height) of mangrove trees, and soil sampling is done in a composite manner in each plot. Mangrove biomass calculations done using allometric equations. Then, biomass is converted to carbon stock and $\mathrm{CO}_{2}$ sequestration, where the percentage value of carbon was 0.47 of biomass. As for the organic soil carbon calculation is done by multiplying the bulk density values, the percentage value of 0.47 and a depth of soil carbon. The results showed that the average estimated amount of mangrove biomass, mangrove carbon stocks, soil carbon stocks and $\mathrm{CO}_{2}$ sequestration were 621.46 tons/ha, 289.22 tons/ha, 1819.31 tons/ha and 1074.99 tons/ha. ANOVA analysis results showed that the amount of mangrove biomass, mangrove carbon stock, soil carbon stock and $\mathrm{CO}_{2}$ sequestration between stations were not significantly different ( $p>0.05)$.
\end{abstract}

Keywords: Mangrove, Biomass, Carbon Stock, $\mathrm{CO}_{2}$ Sequestration

\section{PENDAHULUAN}

Pemanasan global merupakan isu lingkungan yang marak dibahas oleh masyarakat dunia. Peningkatan konsentrasi gas rumah kaca terutama $\mathrm{CO}_{2}, \mathrm{CH}_{4}, \mathrm{~N}_{2} \mathrm{O}$, PFC, HFC dan $\mathrm{SF}_{6}$ di atmosfer bumi diyakini merupakan penyebab terjadinya pemanasan global. Kontribusi gas karbon dioksida adalah yang paling dominan sebagai akibat peningkatan aktivitas manusia terhadap hutan yang pada akhirnya menyebabkan terjadinya efek rumah kaca sehingga bisa mempengaruhi bahkan mengubah pola dan jumlah curah hujan, naiknya air laut dan timbulnya berbagai pengaruh aspek ekologi lainnya yang bisa membahayakan kehidupan makhluk hidup di muka bumi.

Diperkirakan emisi yang ditimbulkan oleh deforestasi dan degradasi hutan mencapai sekitar $20 \%$ dari seluruh emisi gas rumah kaca per tahun. Adapun upaya yang dapat dilakukan untuk mencegah dan mengurangi pemanasan global, yakni dengan cara mengurangi emisi gas rumah kaca. REDD (Reducing Emissions from Deforestation and Forest Degradation in Developing) menjadi salah satu isu 
dominan dalam berbagai forum yang menyangkut kehutanan. REDD merupakan sebuah mekanisme internasional yang dimaksudkan untuk memberikan insentif bagi negara berkembang yang berhasil mengurangi emisi dari deforestasi dan degradasi hutan. Berdasarkan Konvensi Perubahan Iklim atau disebut dengan United Nations Framework Convention on Climate Change (UNFCCC), semua negara berkewajiban mengurangi dampak negatif perubahan iklim atas dasar common but differentiated responsibilities, yakni tidak ada target kuntitatif pengurangan emisi. (CIFOR, 2010).

Donato et al., (2011) menyatakan bahwa hutan mangrove memiliki kemampuan asimilasi dan penyerapan karbon yang tinggi. Tinggi rendahnya kandungan karbon dipengaruhi oleh kemampuan hutan tersebut dalam menyerap karbon dari udara melalui proses fotosintesis. Dalam proses fotosintesis, $\mathrm{CO}_{2}$ dari atmosfer diikat oleh vegetasi dan disimpan dalam bentuk biomassa. Dengan mengukur jumlah kandungan karbon yang tersimpan dalam hutan mangrove, maka juga dapat diketahui berapa jumlah $\mathrm{CO}_{2}$ di atmosfir yang diserap oleh hutan tersebut.

Sungai Sembilan merupakan salah satu wilayah industri dan wilayah pesisir yang berada di Kota Dumai, Provinsi Riau yang memiliki bentangan mangrove di sepanjang pesisir pantai. Pada kawasan tersebut masih ditemukan kegiatankegiatan yang menyebabkan kerusakan hutan seperti penebangan pohon secara liar untuk bahan bangunan dan panglong arang, konversi lahan hutan menjadi lahan industri serta pencemaran yang disebabkan oleh kegiatan industri.

Kegiatan-kegiatan tersebut tentunya akan berdampak pada berkurangnya tingkat kerapatan pada hutan mangrove sehingga menyebabkan daya dukung hutan mangrove dalam menyerap karbon berkurang. Untuk mengantisipasi kerusakan hutan mangrove yang lebih serius, maka perlu usaha-usaha yang serius dalam pengelolaannya. Sementara itu, belum didapatkan informasi mengenai besaran jumlah karbon yang dapat disimpan dan diserap oleh hutan mangrove pada kawasan tersebut. Atas dasar itu, perlu dilakukan penelitian mengenai estimasi stok karbon tersimpan pada hutan mangrove di Kecamatan Sungai Sembilan, Kota Dumai, Provinsi Riau.

\section{METODE PENELITIAN}

Penelitian dilaksanakan pada bulan Juli 2019 di wilayah pesisir Kecamatan Sungai Sembilan, Kota Dumai, Provinsi Riau (Gambar 1).

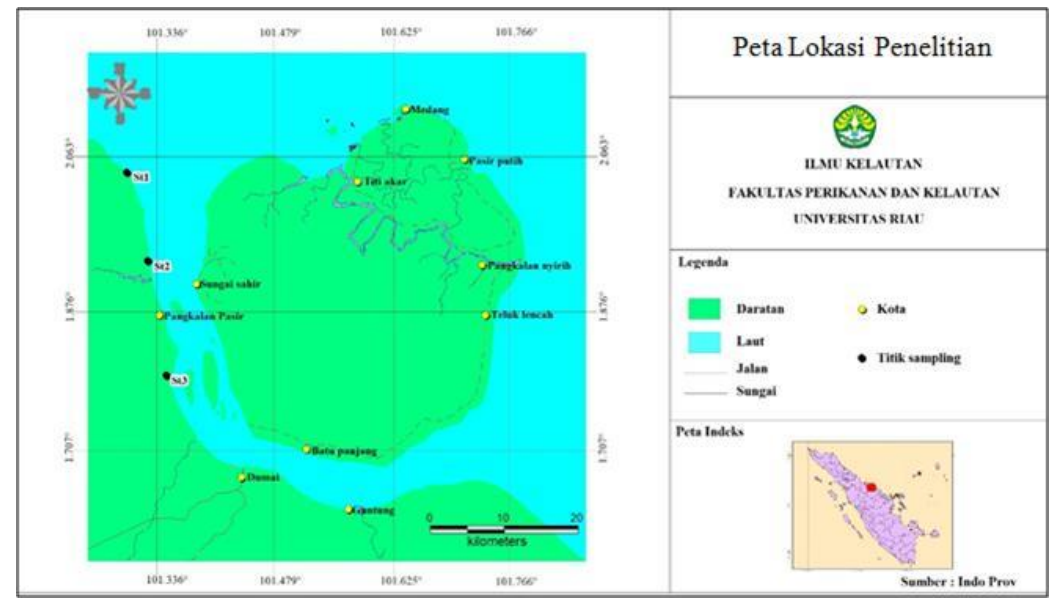

Gambar 1. Peta Lokasi Penelitian 
Penelitian ini dilakukan dengan menggunakan metode survey, dimana pengamatan dan pengambilan sampel dilakukan secara langsung di lokasi penelitian.

Penentuan stasiun dilakukan dengan menggunakan metode purposive sampling, yaitu dengan cara menentukan lokasi secara sengaja dengan mempertimbangkan serta memperhatikan kondisi lokasi penelitian di sekitarnya. Adapun pembagian stasiun pada penelitian ini adalah sebagai berikut.

1. Stasiun 1 berada di kawasan hutan mangrove pantai Santa Hulu, Kelurahan Batu Teritip. Pada kawasan ini terdapat panglong arang, dimana masyarakat setempat memanfaatkan pohon mangrove sebagai bahan baku pembuatan arang.

2. Stasiun 2 berada di kawasan hutan mangrove Muara Sungai Geniot, Kelurahan Basilam Baru. Kawasan ini merupakan kawasan hutan mangrove yang berada di dekat pemukiman penduduk.
3. Stasiun 3 berada di kawasan hutan mangrove perairan Tanjung Penyembal, Kelurahan Tanjung Penyembal. Kawasan ini merupakan kawasan hutan mangrove yang berada jauh dari pemukiman penduduk.

Pengamatan dilakukan dengan metode line transect plot, dimana setiap stasiun terdiri dari 3 transek dan setiap transek terdapat 3 petak plot dengan ukuran $10 \times 10 \mathrm{~m}^{2}$.

\section{Biomassa Mangrove}

Pengambilan data biomassa mangrove dilakukan secara non destructive dengan mengukur DBH (Diameter at Breast Height) pohon berdasarkan Badan Standarisasi Nasional (2011).

Perhitungan jumlah biomassa mangrove pada penelitian ini menggunakan persamaan allometrik. Adapun persamaan allometrik yang mengacu Komiyama et al., (2008) (Tabel 1).

Tabel 1. Perhitungan Jumlah mangrove menggunakan persamaan allometrik

\begin{tabular}{|c|c|c|}
\hline Nama Spesies & Above Ground Biomass (AGB) & Below Ground Biomass (BGB) \\
\hline Rhizophora apiculata & $\begin{array}{l}\mathrm{W}_{\text {top }}=0,235 \mathrm{DBH}^{2,42} \\
\text { (Ong et al. } 2004)\end{array}$ & $\begin{array}{c}\mathrm{W}_{\mathrm{R}}=0,00698 \mathrm{DBH}^{2,61} \\
(\text { Ong et al. } 2004)\end{array}$ \\
\hline Sonneratia alba & $\begin{array}{l}\mathrm{W}_{\text {top }}=0,251 \mathrm{p} \mathrm{DBH}{ }^{2,46} \\
(\text { Komiyama et al. } 2005)\end{array}$ & $\begin{array}{l}\mathrm{W}_{\mathrm{R}}=0,199 \mathrm{p}^{0,899} \mathrm{DBH}^{2,22} \\
\text { (Komiyama et al. } 2005 \text { ) }\end{array}$ \\
\hline Xilocarpus granatum & $\begin{array}{l}\mathrm{W}_{\text {top }}=0,0823 \mathrm{DBH}^{2,59} \\
(\text { Clough and Scott, } 1989)\end{array}$ & $\begin{array}{c}\mathrm{W}_{\mathrm{R}}=0,145 \mathrm{DBH}^{2,55} \\
(\text { Poungparn } \text { et al. } 2002 \text { ) }\end{array}$ \\
\hline Lumnitzera littorea & $\begin{array}{l}\mathrm{W}_{\text {top }}=0,251 \mathrm{p} \mathrm{DBH} \mathrm{DB}^{2,46} \\
(\text { Komiyama et al. } 2005)\end{array}$ & $\begin{array}{l}\mathrm{W}_{\mathrm{R}}=0,199 \mathrm{p}^{0,899} \mathrm{DBH}^{2,22} \\
\text { (Komiyama et al. } 2005 \text { ) }\end{array}$ \\
\hline Scyphiphora hydrophyllaceae & $\begin{array}{l}\mathrm{W}_{\text {top }}=0,251 \mathrm{p} \mathrm{DBH} \mathrm{DB}^{2,46} \\
(\text { Komiyama et al. } 2005)\end{array}$ & $\begin{array}{l}\mathrm{W}_{\mathrm{R}}=0,199 \mathrm{p}^{0,899} \mathrm{DBH}^{2,22} \\
\text { (Komiyama et al. } 2005 \text { ) }\end{array}$ \\
\hline Bruguiera gymnorrhiza & $\begin{array}{l}\mathrm{W}_{\text {top }}=0,186 \mathrm{DBH}^{2,31} \\
(\text { Clough and Scott, 1989) }\end{array}$ & $\begin{array}{l}\mathrm{W}_{\mathrm{R}}=0,199 \mathrm{p}^{0,899} \mathrm{DBH}^{2,22} \\
\text { (Komiyama et al. } 2005 \text { ) }\end{array}$ \\
\hline Excoecaria agallocha & $\begin{array}{l}\mathrm{W}_{\text {top }}=0,251 \mathrm{p} \mathrm{DBH} \mathrm{DB}^{2,46} \\
(\text { Komiyama et al. } 2005)\end{array}$ & $\begin{array}{l}\mathrm{W}_{\mathrm{R}}=0,199 \mathrm{p}^{0,899} \mathrm{DBH}^{2,22} \\
\text { (Komiyama et al. } 2005 \text { ) }\end{array}$ \\
\hline Ceriops tagal & $\begin{array}{c}\mathrm{W}_{\text {top }}=0,189 \mathrm{DBH}^{2,59} \\
(\text { Clough and Scott, 1989) }\end{array}$ & $\begin{array}{c}\mathrm{W}_{\mathrm{R}}=0,159 \mathrm{DBH}^{1,95} \\
(\text { Comley and McGuinness, 2005) }\end{array}$ \\
\hline Avicennia marina & $\begin{array}{c}\mathrm{W}_{\text {top }}=0,308 \mathrm{DBH}^{2,11} \\
\text { (Comley and McGuinness, } \\
\text { 2005) }\end{array}$ & $\begin{array}{c}\mathrm{W}_{\mathrm{R}}=1,28 \mathrm{DBH}^{1,17} \\
\text { (Comley and McGuinness, 2005) }\end{array}$ \\
\hline $\begin{array}{l}\text { Keterangan : } \\
\mathrm{W}_{\text {top }}: \text { Biomassa atas }(\mathrm{kg}) \\
\mathrm{W}_{\mathrm{R}}: \text { Biomassa bawah }(\mathrm{kg})\end{array}$ & $\mathrm{DBH}:$ & $\begin{array}{l}\text { meter pohon yang diuk } \\
\text { nggi dada } \\
\text { a jenis kayu }\left(\mathrm{g} \mathrm{cm}^{-3}\right)\end{array}$ \\
\hline
\end{tabular}


Untuk beberapa spesies yang menggunakan massa jenis kayu dalam menentukan nilai biomassa, dapat digunakan nilai massa jenis kayu berdasarkan Kauffman and Donato (2012) (Tabel 2).

Tabel 2. Massa Jenis Kayu pada Beberapa Spesies Mangrove

\begin{tabular}{cc}
\hline Nama Spesies & Massa Jenis Kayu $\left(\mathrm{g} \mathrm{cm}^{-3}\right)$ \\
\hline Sonneratia alba & 0,078 \\
Lumnitzera littorea & 0,737 \\
Scyphiphora hydrophyllaceae & 0,884 \\
Bruguiera gymnorrhiza & 0,860 \\
Excoecaria agallocha & 0,450 \\
\hline
\end{tabular}

\section{Stok Karbon Mangrove}

Perhitungan karbon pada mangrove menggunakan rumus yang mengacu pada Badan Standardisasi Nasional (2011) yaitu, Keterangan :

$$
\boldsymbol{C b}=\boldsymbol{B} \times \mathrm{C} \text { Organik }
$$

$$
\begin{array}{lll}
\mathrm{Cb} & = & \text { Stok karbon }(\mathrm{kg}) \\
\mathrm{B} & = & \text { Total Biomassa }(\mathrm{kg}) \\
\% \mathrm{C} \text { organik } & = & \text { Nilai persentase karbon } \\
& \text { sebesar } 0,47
\end{array}
$$$$
\text { Cbh }=\frac{C x}{1000} x \frac{10000}{\text { Lplot }}
$$

Keterangan:

Cbh : Stok karbon per hektar(ton/ha).

$C x$ : Stok karbon (kg).

Lplot : Luas plot $\left(\mathrm{m}^{2}\right)$.

\section{Stok Karbon Tanah}

Pengambilan data stok karbon organik tanah dilakukan dengan mengacu pada Badan Standarisasi Nasional (2011) yaitu sebagai berikut.

1. Sampel tanah diambil dari lima sub plot, yakni empat sub plot yang berada di sudut dan satu sub plot di bagian tengah.

2. Sampel tanah diambil dengan metode komposit, yaitu mencampurkan contoh tanah dari kelima titik contoh menjadi satu.

3. Sampel tanah diambil dari lima sub plot pada kedalaman 0-5 cm dengan menggunakan pipa paralon.
4. Sampel tanah ditimbang massa basahnya dan dikeringkan di laboratorium dengan menggunakan oven pada suhu $\pm 100^{\circ} \mathrm{C}$ selama 48 jam.

5. Sampel tanah ditimbang dan dicatat massa keringnya.

Perhitungan karbon pada tanah menggunakan rumus yang mengacu Badan Standardisasi Nasional (2011) yaitu:

$$
C t=K d \times p \times \% \text { Organik }
$$

Keterangan :

\begin{tabular}{|l|l|l|}
\hline $\mathrm{Ct}$ & $:$ & $\begin{array}{l}\text { Stok karbon organik tanah } \\
\left(\mathrm{gr} / \mathrm{cm}^{2}\right) .\end{array}$ \\
\hline $\mathrm{Kd}$ & $:$ & Kedalaman tanah $(\mathrm{cm})$ \\
\hline$p$ & $:$ & Bulk density $\left(\mathrm{g} / \mathrm{cm}^{3}\right)$ \\
\hline
\end{tabular}

Keterangan:

$$
\text { Cth }=\text { Ct } x 100
$$

Cth : Stok karbon tanah per hektar (ton/ha).

Ct : Stok karbon organik tanah $\left(\mathrm{gr} / \mathrm{cm}^{2}\right)$.

100 : Faktor konversi gr/ $\mathrm{cm}^{2} \mathrm{ke}$ ton/ha.

\section{Stok Karbon Total}

Perhitungan stok karbon total dapat menggunakan rumus yang mengacu Badan Standardisasi Nasional (2011), yaitu :

$$
\text { Ctot }=C b h+C t h
$$

Keterangan :

Ctot : Stok karbon total(ton/ha). 
Cbh : Stok karbon mangrove per hektar (ton/ha).

Cth : Stok karbon tanah per hektar (ton/ha).

\section{Serapan Gas $\mathrm{CO}_{2}$}

Perhitungan

serapan gas

karbondioksida dapat menggunakan rumus yang mengacu Bismark et al (2008), yaitu :

Keterangan :

$$
\mathrm{SCO}_{2}=\frac{\mathrm{MrCO}}{\mathrm{ArC}} \times \mathrm{KC}
$$

$\mathrm{SCO}_{2} \quad$ : Serapan gas $\mathrm{CO}_{2}(\mathrm{~kg})$.

$\mathrm{MrCO}_{2}$ : Massa molekul relatif atom C sebesar 44.

$\mathrm{ArC}$ :Atom relatif atom $\mathrm{C}$ sebesar 12.

Kc :Kandungan karbon $(\mathrm{kg})$.

Keterangan :

$$
S n=\frac{S C O_{2}}{1000} \times \frac{10000}{\text { Lplot }}
$$

$\mathrm{Sn} \quad$ : Serapan gas $\mathrm{CO}_{2}$ per hektar

$$
\text { (ton/ha). }
$$

$\mathrm{SCO}_{2}$ : Serapan gas $\mathrm{CO}_{2}(\mathrm{~kg})$.

Lplot : Luas plot $\left(\mathrm{m}^{2}\right)$.

\section{Kerapatan Tegakan Mangrove}

Nilai kerapatan dapat dihitung dengan cara sebagai berikut.

Keterangan:

$$
K=\frac{n i}{A}
$$

$K \quad$ : Kerapatan suatu jenis (ind $/ \mathrm{m}^{2}$ ).

ni : Jumlah individu.

A : Luas seluruh plot $\left(\mathrm{m}^{2}\right)$.

\section{Analisis Data}

Analisis data yang digunakan pada penelitian adalah Uji ANOVA dan Uji Regresi Linear. Uji ANOVA digunakan untuk membandingkan biomassa, stok karbon dan serapan $\mathrm{CO}_{2}$ antar stasiun. Uji Regresi Linear digunakan untuk mengetahui tingkat hubungan antara kerapatan tegakan mangrove dengan variabel lainnya (biomassa, stok karbon dan serapan karbondioksida), dengan merujuk pada Sugiyono (2007) (Tabel.3).

Tabel 3. Pedoman untuk Memberikan Interpretasi Koefisien Korelasi

\begin{tabular}{cc}
\hline Interval Koefisien & Tingkat Hubungan \\
\hline $0,00-0,199$ & Sangat Rendah \\
$0,20-0,399$ & Rendah \\
$0,40-0,599$ & Sedang \\
$0,60-0,799$ & Kuat \\
$0,80-1,000$ & Sangat Kuat \\
\hline
\end{tabular}

\section{HASIL DAN PEMBAHASAN}

Kondisi Umum Lokasi Penelitian

Adapun hasil pengukuran kualitas lingkungan dapat dilihat pada Tabel 4.

Tabel 4. Hasil Pengukuran Parameter Kualitas Lingkungan

\begin{tabular}{cccc}
\hline Stasiun & $\begin{array}{c}\text { Suhu } \\
\left({ }^{0} \mathrm{C}\right)\end{array}$ & pH & $\begin{array}{c}\text { Salinitas } \\
\left(\% \%_{00}\right)\end{array}$ \\
\hline I & 29 & 7 & 27 \\
II & 28 & 6 & 27 \\
III & 29 & 7 & 28 \\
\hline
\end{tabular}

Berdasarkan nilai parameter kualitas lingkungan di atas, diperoleh nilai yang tidak berbeda jauh pada parameter suhu, $\mathrm{pH}$ dan salinitas antar stasiun.

\section{Komposisi Vegetasi dan Kerapatan Mangrove}

Vegetasi mangrove yang ditemukan pada 3 stasiun penelitian terdiri atas 9 spesies, yaitu: Rhizophora apiculata, Sonneratia alba, Xilocarpus granatum, Lumnitzera littorea, , Bruguiera gymnorrhiza, Avicennia marina, Excoecaria agallocha, Ceriops tagal, dan Scyphiphora hydrophyllaceae.

Dari hasil penelitian yang telah dilakukan, kerapatan tegakan pada hutan mangrove di wilayah pesisir Kecamatan Sungai Sembilan, Kota Dumai dapat dilihat pada Gambar 1. 


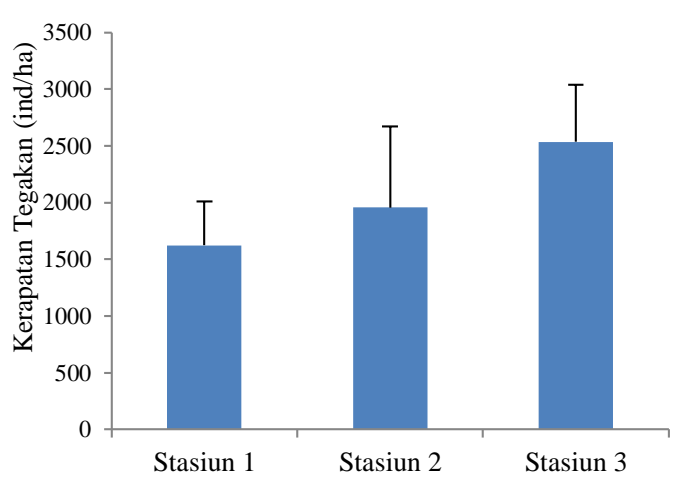

Gambar 1. Kerapatan Tegakan Mangrove

Berdasarkan data pada Gambar 1. terlihat bahwa Stasiun 3 memiliki kerapatan tegakan mangrove yang tertinggi, yaitu 2533,33 ind/ha, sedangkan kerapatan yang terdapat pada Stasiun 1 dan Stasiun 2, yaitu 1622,22 ind/ha dan 1955,56 ind/ha. Kerapatan tegakan mangrove pada Stasiun 3 lebih tinggi dibandingkan Stasiun 1 dan Stasiun 2 dikarenakan karakteristik yang berbeda pada ketiga wilayah stasiun penelitian, dimana Stasiun 3 merupakan wilayah hutan mangrove yang berada jauh dari pemukiman penduduk sehingga pemanfaatan hutan yang terjadi pada wilayah tersebut tergolong minim.

Stasiun lainnya merupakan wilayah hutan mangrove yang terkena dampak oleh pemanfaatan oleh penduduk yang tergolong lebih besar, seperti pada Stasiun 2 yang merupakan wilayah yang berada di dekat pemukiman masyarakat, dimana pada wilayah tersebut masyarakat memanfaatkan kayu dan lahan untuk membangun pemukimannya, serta Stasiun 1 yang merupakan wilayah yang berada di dekat panglong arang, dimana penduduk sekitar memanfaatkan kayu tersebut sebagai bahan baku pembuatan arang, hal tersebut diduga sebagai penyebab kerapatan tegakan mangrove pada wilayah tersebut lebih rendah dibandingkan stasiun lainnya.

Hasil analisis uji ANOVA menunjukkan kerapatan tegakan mangrove antar stasiun penelitian tidak berbeda nyata ( $\mathrm{p}=0,204$ atau $\mathrm{p}>0,05$ )Adapun kategori kondisi hutan mangrove setiap stasiun berdasarkan kerapatan tegakan mangrove dapat dilihat pada tabel 5 .

Tabel 5. Kategori Kerapatan Mangrove

\begin{tabular}{cccc}
\hline Stasiun & $\begin{array}{c}\text { Kerapatan } \\
\text { (Ind/ha) }\end{array}$ & Kriteria & Kondisi \\
\hline Stasiun 1 & 1622,22 & Baik & Padat \\
Stasiun 2 & 1955,56 & Baik & Padat \\
Stasiun 3 & 2533,33 & Baik & Padat \\
\hline
\end{tabular}

Kriteria kerapatan padat terdeteksi pada Tahun 2018 yaitu terdapat pada Sungai Gangsal dengan kerapatan 1.522 ind/ha sampai $1.511 \mathrm{ind} / \mathrm{ha}$ (Susilo et al., 2019). Berdasarkan kriteria baku kerusakan mangrove yang ditetapkan oleh Menteri Negara Lingkungan Hidup (2004), yaitu kerapatan padat $\geq 1500 \mathrm{ind} / \mathrm{ha}$, sedang $\geq$ $1000 \leq 1500 \mathrm{ind} / \mathrm{ha}$ dan jarang $<1000 \mathrm{ind} / \mathrm{ha}$, maka dapat disimpulkan bahwa ketiga stasiun penelitian memiliki kerapatan tegakan mangrove dalam kategori padat.

\section{Biomassa Mangrove}

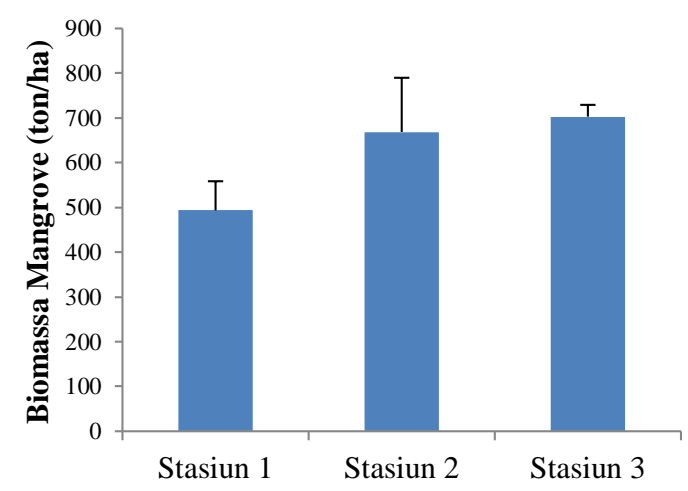

Gambar 2. Estimasi Biomassa Mangrove

Hasil perhitungan estimasi kandungan biomassa pada ketiga stasiun penelitian menunjukkan bahwa total biomassa tertinggi terdapat pada Stasiun 3, yaitu sebesar 702,69 ton/ha, sedangkan total biomassa terendah terdapat pada Stasiun 1, yaitu sebesar 493,81 ton/ha. Perbedaan jumlah biomassa tersebut terjadi dikarenakan tingkat kerapatan tegakan mangrove pada Stasiun 3 lebih tinggi dibandingkan dengan Stasiun 1 dan Stasiun 
2. Pernyataan tersebut juga diperkuat oleh Irsadi et al. (2017), yang menyatakan bahwa kerapatan mangrove memiliki korelasi positif atau berbanding lurus terhadap kandungan biomassa, sehingga dapat disimpulkan bahwa apabila kerapatan tegakan pada suatu ekosistem mangrove tinggi, maka jumlah biomassa yang terkandung dalam ekosistem tersebut juga tinggi, begitu juga sebaliknya.

Selain tingkat kerapatan tegakan mangrove, besarnya diameter juga dapat mempengaruhi jumlah biomassa. Semakin besar diameter pada suatu tegakan, maka semakin besar pula biomassa yang terdapat pada tegakan tersebut. Pengaruh dari besarnya diameter batang terhadap nilai biomassa suatu tegakan pohon sangat besar, sejalan dengan pendapat Ihsan et al. (2016) bahwa terdapat hubungan erat antara dimensi pohon (diameter dan tinggi) dengan biomassanya, terutama dengan diameter pohon.

Menurut Syam'ani et al. (2012), biomassa pada pohon dapat bertambah karena pohon menyerap $\mathrm{CO}_{2}$ di atmosfer dan mengubahnya menjadi senyawa organik dari proses fotosintesis, hasil fotosintesis digunakan oleh pohon untuk melakukan pertumbuhan ke arah horizontal dan vertikal ditandai dengan bertambahnya diameter dan tinggi. Melalui proses fotosintesis, $\mathrm{CO}_{2}$ diserap oleh tumbuhan dengan bantuan sinar matahari kemudian diubah menjadi karbohidrat untuk selanjutnya didistribusikan ke seluruh tubuh tumbuhan dan ditimbun dalam bentuk daun, batang, cabang, buah dan bunga (Hairiah et al. 2011).

Berdasarkan hasil penelitian, diketahui bahwa rata-rata biomassa mangrove di hutan mangrove Kecamatan Sungai Sembilan, Kota Dumai adalah sebesar 621,46 ton/ha. Jumlah tersebut lebih tinggi dibandingkan dengan penelitian yang pernah dilakukan oleh Heriyanto dan Subiandono (2016) di Kecamatan Teluk Pekedai, Kubu Raya, Kalimantan Barat dengan rata-rata biomassa yaitu sebesar 438,79 ton/ha.

Hasil analisis uji ANOVA menunjukkan jumlah biomassa mangrove antar stasiun penelitian tidak berbeda nyata $(\mathrm{p}=0,56$ atau $\mathrm{p}>0,05)$.

\section{Stok Karbon Mangrove}

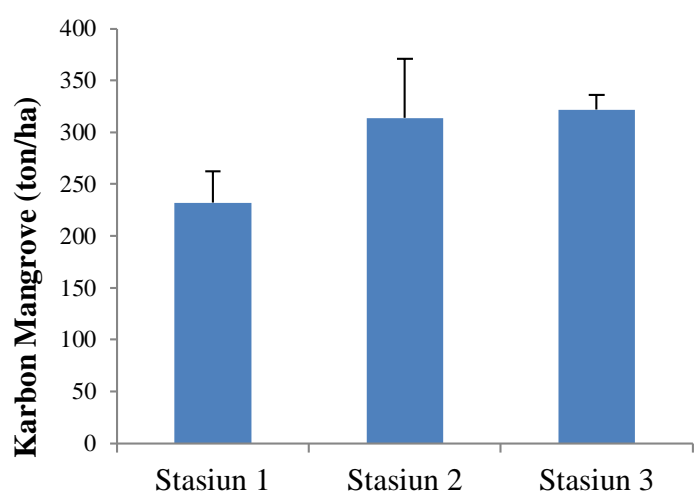

Gambar 3. Estimasi Karbon Mangrove

Hasil perhitungan estimasi kandungan karbon pada ketiga stasiun penelitian menunjukkan bahwa total karbon tertinggi terdapat pada Stasiun 3, yaitu sebesar 321,66 ton/ha, sedangkan total karbon terendah terdapat pada Stasiun 1, yaitu sebesar 232,09 ton/ha. Perbedaan stok karbon mangrove ini terjadi dikarenakan tingkat kerapatan tegakan mangrove pada Stasiun 3 lebih besar dibandingkan dengan stasiun lainnya.

Selain tingkat kerapatan, jumlah biomassa pada tegakan mangrove pada suatu vegetasi juga mempengaruhi besarnya jumlah karbon yang disimpan oleh vegetasi tersebut. Besar kecilnya simpanan karbon dalam suatu vegetasi bergantung pada jumlah biomassa yang terkandung pada pohon, kesuburan tanah dan daya serap vegetasi tersebut (Ati et al., 2014).

Menurut Heriyanto dan Subiandono (2012), kandungan karbon pada tumbuhan menggambarkan berapa besar tumbuhan tersebut dapat mengikat $\mathrm{CO}_{2}$ dari udara. Tumbuhan menyerap $\mathrm{CO}_{2}$ dari udara 
kemudian mengkonversinya menjadi bahan organik melalui proses fotosintesis yang digunakan untuk pertumbuhan. Apabila suatu hutan mangrove telah rusak disebabkan oleh faktor alam seperti abrasi dan tsunami atau disebabkan oleh campur tangan manusia seperti penebangan pohon untuk kebutuhan kayu dan alih fungsi lahan seperti kawasan industri, maka jumlah karbon yang tersimpan akan semakin mengalami penurunan bahkan hilang sehingga karbon terlepas dan menyebabkan emisi karbon. Apabila hal ini terjadi terus menerus, maka akan mengakibatkan peningkatan karbondioksida di udara hingga terjadinya pemanasan global.

Berdasarkan hasil penelitian, diketahui bahwa rata-rata stok karbon mangrove di hutan mangrove Kecamatan Sungai Sembilan, Kota Dumai adalah sebesar 289,22 ton/ha. Jumlah tersebut lebih tinggi dibandingkan dengan penelitian yang dilakukan oleh Heriyanto dan Subiandono (2016) di Kecamatan Teluk Pekedai, Kubu Raya, Kalimantan Barat dengan rata-rata stok karbon sebesar 219,53 ton/ha.

Hasil analisis uji ANOVA menunjukkan jumlah stok karbon mangrove antar stasiun penelitian tidak berbeda nyata $(\mathrm{p}=0,597$ atau $\mathrm{p}>0,05)$

\section{Serapan $\mathrm{CO}_{2}$}

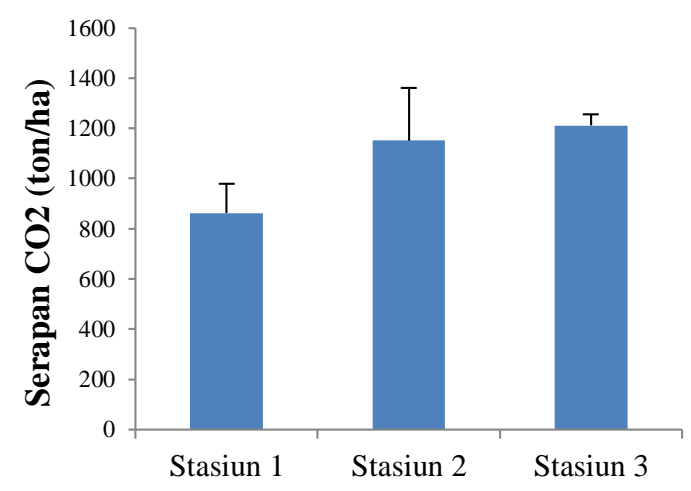

Gambar 4. Estimasi Serapan $\mathrm{CO}_{2}$
Hasil perhitungan estimasi penyerapan $\mathrm{CO}_{2}$ dalam pada ketiga stasiun penelitian menunjukkan bahwa total serapan $\mathrm{CO}_{2}$ tertinggi terdapat pada Stasiun 3 , yaitu sebesar 1211,25 ton/ha, sedangkan yang terendah terdapat pada Stasiun 1, yaitu sebesar 862,7 ton/ha.

Chanan (2012) menyatakan bahwa biomassa dan kandungan karbon tersimpan pada hutan memiliki korelasi yang positif sehingga apapun yang menyebabkan peningkatan atau penurunan biomassa, maka akan menyebabkan peningkatan atau penurunan juga terhadap kandungan karbon pada hutan tersebut. Begitu juga halnya dengan serapan $\mathrm{CO}_{2}$ pada hutan mangrove. Serapan $\mathrm{CO}_{2}$ juga memiliki korelasi yang positif terhadap biomassa dan kandungan karbon.

Ekosistem mangrove di wilayah pesisir sangat efektif dan efisien dalam mengurangi konsentrasi $\mathrm{CO}_{2}$ di atmosfer, dikarenakan mangrove dapat menyerap $\mathrm{CO}_{2}$ melalui proses fotosintesis dengan cara difusi lewat stomata kemudian menyimpan karbon dalam bentuk biomassa (Windardi, 2014). Maka dari itu sebagian besar biomassa pada vegetasi mangrove merupakan karbon dan nilai karbon yang terkandung dalam vegetasi mangrove merupakan potensi dari vegetasi mangrove tersebut dalam menyerap $\mathrm{CO}_{2}$.

Berdasarkan hasil penelitian, diketahui bahwa rata-rata serapan $\mathrm{CO}_{2}$ di hutan mangrove Kecamatan Sungai Sembilan, Kota Dumai adalah sebesar 1074,99 ton/ha. Jumlah tersebut lebih tinggi dibandingkan dengan penelitian yang dilakukan oleh Heriyanto dan Subiandono (2016) di Kecamatan Teluk Pekedai, Kubu Raya, Kalimantan Barat dengan rata-rata serapan $\mathrm{CO}_{2}$ yaitu sebesar 805,68 ton/ha.Hasil analisis uji ANOVA menunjukkan jumlah serapan $\mathrm{CO}_{2}$ antar stasiun penelitian tidak berbeda nyata $(\mathrm{p}=$ 0,586 atau $\mathrm{p}>0,05$ ) 


\section{Karbon Tanah}

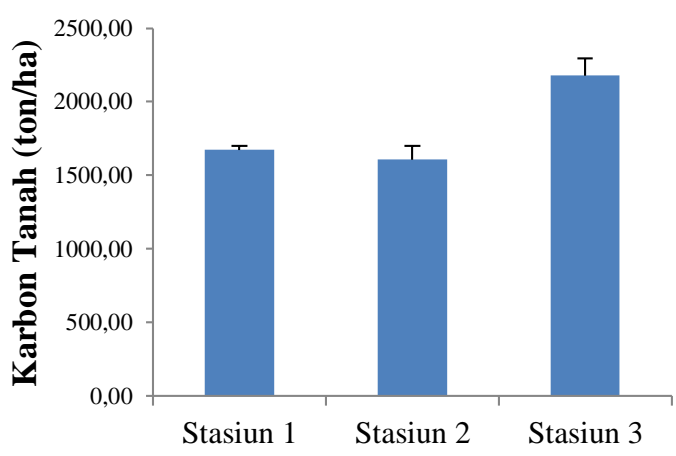

Gambar 5. Estimasi Karbon Tanah

Hasil perhitungan estimasi karbon tanah pada ketiga stasiun penelitian menunjukkan bahwa total karbon tanah tertinggi terdapat pada Stasiun 1, yaitu sebesar 2178,14 ton/ha, sedangkan yang terendah terdapat pada Stasiun 2, yaitu sebesar 1607,61 ton/ha. Tingginya stok karbon tanah pada Stasiun 3 disebabkan oleh tingkat kerapatan tegakan mangrove yang lebih tinggi dan banyaknya jumlah vegetasi mangrove yang ditemukan dibandingkan stasiun lainnya sehingga produksi serasah pada kawasan tersebut juga tinggi. Menurut Windarni et al. (2018) semakin besar dan rapat suatu vegetasi hutan mangrove, maka kemampuannya untuk memproduksi serasah organik yang merupakan penyusun utama bahan organik dalam tanah juga tinggi.

Selain itu diduga jenis substrat tanah juga mempengaruhi besar kecilnya jumlah karbon yang terkandung dalam tanah. Jenis substrat pasir cenderung lebih kecil dibandingkan substrat lumpur (Lestariningsih et al., 2018). Dengan banyaknya pori-pori makro, maka tanah dengan dominasi pasir akan memiliki kemampuan menahan air yang sangat rendah, sehingga kerapatan tanahnya rendah. Selain itu, kondisi tanah tersebut akan mudah mengalami pencucian. Pencucian terjadi akibat adanya pasang surut air laut (Mahasani et al., 2015). Sehingga pada Stasiun 3 yang jenis substratnya didominasi oleh lumpur memiliki jumlah karbon lebih besar dibandingkan dengan stasiun 1 dan 2.

Berdasarkan hasil penelitian, diketahui bahwa rata-rata stok karbon tanah di hutan mangrove Kecamatan Sungai Sembilan, Kota Dumai adalah sebesar 1819,31 ton/ha. Jumlah tersebut lebih tinggi dibandingkan dengan penelitian yang dilakukan oleh Hanif (2018) di desa Anak Setatah, Kecamatan Rangsang Barat dengan rata-rata stok karbon sebesar 1546,81 ton/ha.

Hasil analisis uji ANOVA menunjukkan jumlah karbon tanah antar stasiun penelitian tidak berbeda nyata $(\mathrm{p}=$ 0,069 atau $\mathrm{p}>0,05$ )

\section{Stok Karbon Total}

Tabel 6. Estimasi Stok Karbon Mangrove, Karbon Tanah dan Karbon Total

\begin{tabular}{cccc}
\hline Stasiun & $\begin{array}{c}\text { Stok Karbon } \\
\text { Mangrove } \\
\text { (ton/ha) }\end{array}$ & $\begin{array}{c}\text { Stok } \\
\text { Karbon } \\
\text { Tanah } \\
\text { (ton/ha) }\end{array}$ & $\begin{array}{c}\text { Stok } \\
\text { Karbon } \\
\text { Total } \\
\text { (ton/ha) }\end{array}$ \\
\hline 1 & 232,09 & 1672,18 & 1904,27 \\
2 & 313,92 & 1607,41 & 1921,33 \\
3 & 321,66 & 2178,14 & 2499,80 \\
\hline
\end{tabular}

Berdasarkan data di atas, maka terlihat bahwa Stasiun 3 memiliki stok karbon total terbesar, yaitu 2499,80 ton/ha. Sedangkan stok karbon total terendah terdapat pada Stasiun 1, yaitu sebesar 1904,27 ton/ha.

\section{Hubungan Kerapatan Tegakan Mangrove terhadap Jumlah Biomassa, Karbon Mangrove dan Serapan $\mathrm{CO}_{2}$}

Berdasarkan penelitian yang telah dilakukan, maka hubungan antara kerapatan tegakan mangrove terhadap jumlah biomassa, karbon mangrove dan serapan $\mathrm{CO}_{2}$ dapat dilihat pada Gambar 6 . Untuk mengetahui seberapa erat hubungan tersebut, maka dilakukan uji regresi antara kerapatan tegakan mangrove terhadap 
biomassa, karbon mangrove dan serapan $\mathrm{CO}_{2}$.
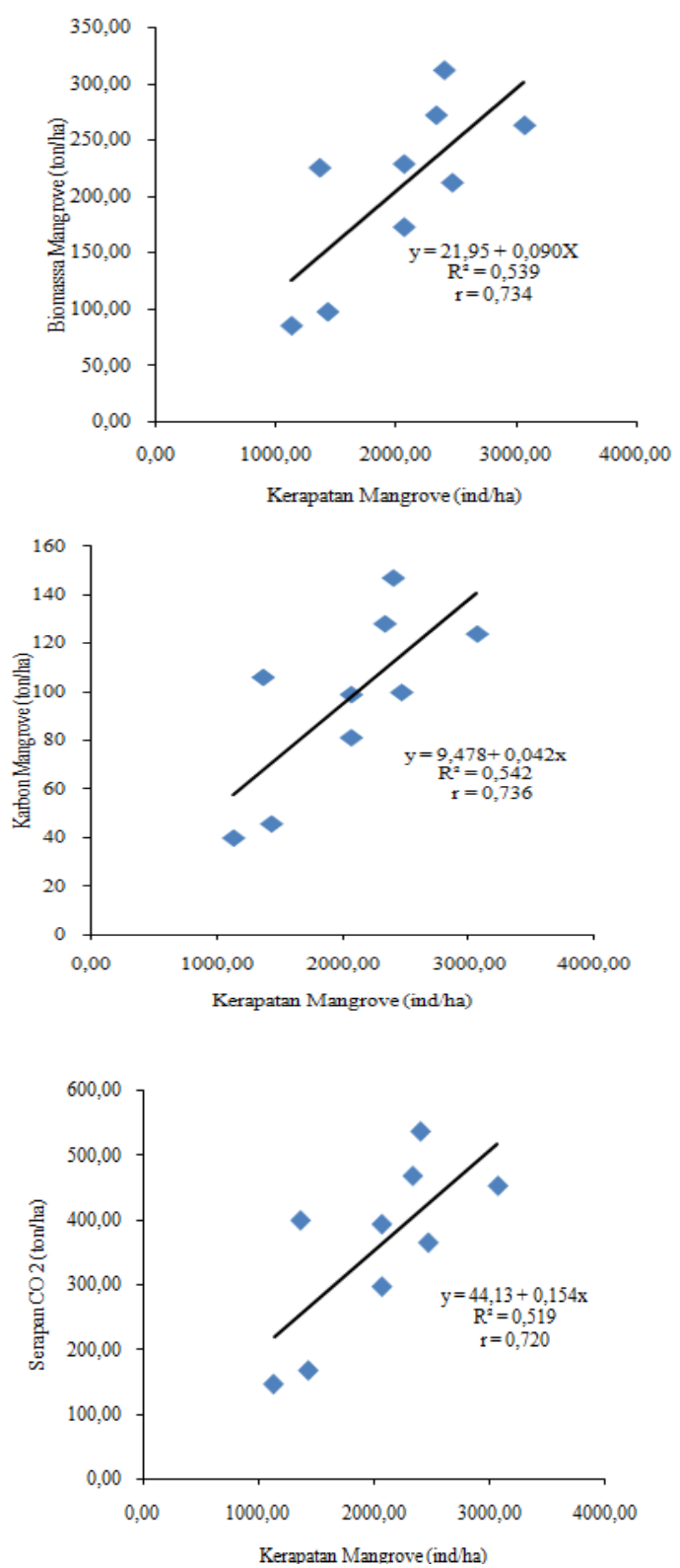

Gambar 6. Hubungan Kerapatan terhadap Biomassa, Karbon Mangrove dan Serapan $\mathrm{CO}_{2}$

Berdasarkan Gambar 6. maka terlihat bahwa nilai korelasi dari hubungan kerapatan tegakan mangrove terhadap biomassa yaitu 0,734 , terhadap karbon mangrove yaitu 0,736 dan terhadap serapan $\mathrm{CO}_{2}$ yaitu 0,720. Berdasarkan Sugiono (2007), maka hubungan kerapatan tegakan mangrove terhadap jumlah biomassa, karbon mangrove dan serapan $\mathrm{CO}_{2}$ memiliki tingkat hubungan yang kuat, yaitu dimana semakin tinggi nilai kerapatan tegakan mangrove, maka semakin tinggi pula jumlah biomassa, karbon mangrove dan serapan $\mathrm{CO}_{2}$ pada hutan mangrove tersebut.

\section{KESIMPULAN DAN SARAN Kesimpulan}

Kondisi kerapatan tegakan mangrove pada ketiga stasiun penelitian dikategorikan baik (padat), dimana kerapatan tegakan mangrove tertinggi terdapat pada Stasiun 3, yaitu sebesar 2533,33 ind/ha. Sedangkan kerapatan tegakan mangrove pada Stasiun 1 dan Stasiun 2, yaitu sebesar 1622,22 dan $1955,56 \mathrm{ind} / \mathrm{ha}$.

Hasil perhitungan estimasi rata-rata biomassa, stok karbon mangrove dan stok karbon organik tanah pada kawasan hutan mangrove Kecamatan Sungai Sembilan yaitu masing-masing sebesar 621,46 ton/ha, 289,22 ton/ha dan 1819,31 ton/ha. Untuk serapan $\mathrm{CO}_{2}$ pada kawasan tersebut didapatkan hasil rata-rata sebesar 1.074,99 ton/ha.

Perbandingan biomassa mangrove, stok karbon dan serapan $\mathrm{CO}_{2}$ antar stasiun berdasarkan hasil uji ANOVA adalah tidak berbeda nyata $(p>0,05)$. Tingkat kerapatan tegakan mangrove memiliki hubungan yang kuat terhadap besarnya biomassa, stok karbon dan serapan $\mathrm{CO}_{2}$ dengan nilai koefisien korelasi masingmasing sebesar 0,$734 ; 0,726$ dan 0,72 .

\section{Saran}

Disarankan pada penelitian selanjutnya dilakukan perhitungan estimasi karbon pada bahan organik mati seperti nekromassa (pohon mati) dan serasah mangrove, serta estimasi stok karbon tanah berdasarkan interval kedalaman tanah yang berbeda pada kawasan hutan mangrove Kecamatan Sungai Sembilan, Kota Dumai, Provinsi Riau. 


\section{DAFTAR PUSTAKA}

1. Ati, RNA., A. Rustam, TL. Kepel, N. Sudirman, M. Astrid, A. Daulat, P. Mangindaan, HL. Salim dan A.A. Hutahaean. (2014). Stok Karbon dan Struktur Komunitas Mangrove sebagai Blue Carbon di Tanjung Lesung, Banten. Jurnal Segara, volume 10(2), pages 98-171.

2. Badan Standardisasi Nasional. (2011). Pengukuran dan Penghitungan Cadangan Karbon - Pengukuran Lapangan untuk penaksiran Cadangan Karbon Hutan (Ground based Forest Carbon Accounting). Gd. Manggala Wanabakti. Jakarta.

3. Bismark, M., NM. Heriyanto dan S. Iskandar. (2008). Biomassa dan Kandungan pada Hutan Produksi di Cagar Biosfer Pulau Siberut, Sumatera Barat. Jurnal Penelitian Hutan dan Konservasi Alam, volume 5(5), pages 397 - 407.

4. Chanan, M. (2012). Pendugaan Cadangan Karbon (C) Tersimpan di Atas Permukaan Tanah pada Vegetasi Hutan Tanaman Jati (Tectona Grandis Linn. F) (di RPH Sengguruh BKPH Sengguruh KPH Malang Perum Perhutani II Jawa Timur). Jurnal GAMMA, volume 7(2), pages 61-73

5. CIFOR, (2010). REDD: Apakah Itu? Pedoman CIFOR tentang Hutan, Perubahan Iklim dan REDD. CIFOR, Bogor, Indonesia.

6. Donato, CD., JB. Kauffman, D. Murdiyarso, S. Kurnianto, M. Stidham dan M. Kanninen. (2011). Mangroves among the Most Carbon-Rich Forests in the Tropics. Nature Geoscience, volume 4, pages 293-297.

7. Hairiah, K., A. Ekadinata, RR. Sari dan S. Rahayu. (2011). Pengukuran Cadangan Karbon dari Tingkat Lahan ke Bentang Lahan. Edisi Kedua. World Agroforestry Centre. ICRAF, SEA Regional Office. University of Brawijaya. Indonesia. 20p.

8. Hanif, N., S.H. Siregar dan B. Amin. (2018). Estimasi Stok Karbon Tersimpan pada Vegetasi Mangrove Desa Anak Setatah, Kecamatan Rangsang Barat, Kabupaten Kepulauan Meranti, Provinsi Riau. Jurnal Online Mahasiswa.

9. Heriyanto, N.M. dan E. Subiandono. 2012. Komposisi dan Struktur Tegakan, Biomasa dan Potensi Kandungan Karbon Hutan Mangrove di Taman Nasional Alas Purwo. Jurnal Penelitian dan Konservasi Alam, volume 9(1), pages 23-32

10. Heriyanto, NM. dan E. Subiandono. (2016). Peran Biomasa Mangrove dalam Menyimpan Karbon di Kubu Raya, Kalimantan Barat. Jurnal Analisis Kebijakan, volume 13(1), pages 1-12.

11. Ihsan, IM., J. Prayitno dan AD. Santoso. (2016). Perhitungan Stok Karbon Hutan Mangrove Probolinggo. Pusat Teknologi Lingkungan. Badan Pengkajian dan Penerapan Teknologi. Banten.

12. Kauffman, JB. and DC. Donato. (2012). Protocols for the Measurent, Monitoring and Reporting of Structure, Biomass and Carbon Stock in Mangrove Forest. Working Paper 86. CIFOR. Bogor, Indonesia.

13. Kementerian Lingkungan Hidup. (2004). Keputusan Menteri Negara Lingkungan Hidup No. 201 tentang Kriteria Baku dan Pedoman Penentuan Kerusakan Mangrove, Jakarta.

14. Komiyama, A., J.E. Ong, and S. Poungparn. (2008). Allometry, Biomass, and Productivity of Mangrove Forest: A Review. Journal of Aquatic Botany. Volume 89, pages $128-137$.

15. Lestariningsih, W.A., N. Soenardjo, dan R. Pribadi. (2018). Estimasi Cadangan Karbon pada Kawasan Mangrove di Desa Timbulsloko, Demak, Jawa Tengah. Buletin Oseanografi Marina. Volume 7(2), pages 121 - 130. 
16. Mahasani, I.G.A.I., N. Windagni dan I.W.G.A. Karang. (2015). Estimasi Persentase Karbon Organik di Hutan Mangrove Bekas Tambak Perancak, Jembrana, Bali. Journal of Marine and Aquatic Sciences. Volume 1, pages 14-18.

17. Sugiyono, D. (2007). Metode Penelitian Pendidikan Pendekatan Kuantitatif dan Kualitatif. Bandung. Alfabeta.

18. Syam'ani, A. Agustina, R. Susilawati dan Y. Nugroho. (2012). Cadangan Karbon di Atas Permukaan Tanah pada Berbagai Sistem Penutupan Lahan di Sub - Sub DAS Amandit. Jurnal Hutan Tropis. Volume 13(2), pages 148-158.

19. Susilo, H., M. Galib., A. Mulyadi. (2019). Mapping Of Mangrove Vegetation Using Landsat Satellite Imagery In The Estuary Of Gangsal River Indragiri Hilir Regency Riau Province. Asian Journal of Aquatic Sciences. Volume 2(3), pages 181-189.

20. Windardi, A.C. (2014). Struktur Komunitas Hutan Mangrove, estimasi Karbon Tersimpan dan Perilaku Masyarakat Sekitar Kawasan Segara Anakan Cilacap. [Thesis]. Program Studi Ilmu Lingkungan. Universitas Jendral Soedirman.

21. Windarni. C., A. Setiawan dan Rusita. (2018). Estimasi Karbon Tersimpan pada Hutan Mangrove di Desa Margasari, Kecamatan Labuhan Maringgai, Kabupaten Lampung Timur. Jurnal Sylva Lestari. Volume 6(1), pages 66-74. 